\title{
Effectiveness of pharmacotherapy for smoking cessation: Umbrella review and quality assessment of systematic reviews
}

\author{
Alemu Sufa Melka ( $\nabla$ alemusufa.melka@uon.edu.au ) \\ Wollega University https://orcid.org/0000-0001-7616-5651 \\ Catherine L Chojenta \\ The University of Newcastle School of Education \\ Elizabeth G Holliday \\ The University of Newcastle \\ Ayele G Bali \\ Haramaya University \\ Deborah J Loxton \\ The University of Newcastle
}

\section{Research}

Keywords: smoking cessation, pharmacotherapy, nicotine replacement therapy, quality

Posted Date: July 30th, 2020

DOI: https://doi.org/10.21203/rs.2.18915/v3

License: () (i) This work is licensed under a Creative Commons Attribution 4.0 International License. Read Full License

Version of Record: A version of this preprint was published at Systematic Reviews on November 24th, 2018. See the published version at https://doi.org/10.1186/s13643-018-0878-3. 


\section{Abstract}

Background: In the long term, smoking cessation can decrease the risk of cancer, stroke, and heart attacks and improve overall survival. This umbrella review aimed to assess the effect of pharmacological interventions on smoking cessation and to evaluate the methodological quality of previously conducted systematic reviews.

Methods: Databases including the Cochrane library, PubMed, MEDLINE, EMBASE, CINAHL, PsycINFO, Web of Science, Scopus and Google Scholar were used to retrieve reviews. Systematic reviews that included only randomized controlled trials designed to assess pharmacotherapeutic interventions supporting abstinence from smoking were considered in this umbrella review. The methodological quality of the included reviews was assessed using the Assessment of Multiple Systematic Reviews 2 (AMSTAR 2) tool, which contains 16 domains. Two authors (AM, AB) screened the titles and abstracts of all reviews obtained by the search strategy, assessed the full text of selected articles for inclusion and extracted data independently. Two authors (AM, $A B)$ also performed a quality appraisal independently. The findings of the studies were narrated qualitatively to describe the evidence regarding the effectiveness of pharmacotherapies for smoking cessation.

Results: Ten reviews were included in this umbrella review. Most of the reviews included in this review reported that Nicotine Replacement Therapy (NRT), bupropion and varenicline and cytisine were effective for smoking cessation. The combination of a nicotine patch with other nicotine formulations was also more effective than monotherapy. Similarly, the combination of nicotine with the non-nicotine therapy varenicline was found to be more effective than varenicline alone. However, the opioid antagonist naltrexone alone was not found to be effective for smoking cessation nor in combination with nicotine replacement therapy. Based on the AMSTAR 2 rating, one review scored high quality, two scored moderate quality, four scored low quality, and three scored critically low quality.

Conclusions: This review revealed that drugs approved by the US Food and Drug Administration (FDA) are effective for smoking cessation. A combination of nicotine patches with other nicotine formulations was also effective for smoking cessation compared to nicotine monotherapy.

\section{Systematic review registration: PROSPERO Registration: CRD42017080906}

\section{Background}

In 2012, the global estimated prevalence of daily tobacco smoking among men and women aged 15 and over was $31.1 \%$ and $6.2 \%$ respectively [1]. Smoking seriously affects almost all organs in the body. Tobacco smoking can lead to many short- and long-term health effects including lung and other organ cancers, chronic bronchitis, emphysema, stroke and heart attack [2]. Tobacco smoking is responsible for $90 \%$ of all cases of lung cancer and $90 \%$ of all deaths due to chronic obstructive pulmonary disease (COPD) [3]. According to the World Health Organization, tobacco smoking kills about six million people globally per annum [4]. Second-hand smoke contains hundreds of chemicals responsible for diseases such as respiratory disorders, cancer, and cardiovascular disease. Combustible chemicals found in tobacco smoke are responsible for disorders such as cancer, cardiovascular, and pulmonary diseases, through mechanisms that involve DNA damage, inflammation, and oxidative stress [5]. Globally, second-hand smoking affects women and children more than men [6, 7]. Tobacco-related disability-adjusted life years (DALYs) account for $4 \%$ of the global burden of disease, with the burden significantly higher for developed nations [8].

Tobacco contains about 4,000 chemicals, of which nicotine is the one responsible for addictive behaviour [9]. During smoking, the nicotine components of tobacco are absorbed through respiratory mucous membranes and enter the bloodstream, and thereby the brain. Upon entering the brain, nicotine stimulates the release of epinephrine and dopamine which in turn increases blood pressure, heart rate, respiration rate and produces pleasurable feelings $[3,9]$.

In the long-term, smoking cessation decreases the risk of cancer, stroke and cardiovascular disease and also improves life expectancy [3, 10]. By improving natural lung function, smoking cessation can also decrease the risk of respiratory infections such as pneumonia, influenza and chronic obstructive pulmonary disease [11]. Kahler et al. and Eddy et al. have shown that smoking cessation was associated with significant reductions in risk of myocardial infarction, stroke and coronary heart disease [12,13]. In the long term, smoking cessation is an effective intervention to reverse the course of atherosclerosis.

The range of available smoking cessation interventions can broadly be categorized as motivational, behavioural/psychological, or pharmacological. The World Health Organization recommends that countries prioritize different smoking cessation strategies depending on their available resources, national health system, and political will to implement the cessation strategies [14]. The World Health Organization recommends treatment of tobacco dependence as one strategy within its comprehensive tobacco-control policy, along with measures such as taxation and price policies, advertising restrictions, dissemination of information and establishment of smoke-free public places [14]. Treatment of tobacco smoking, like any other forms of substance dependence, necessitates pharmacological interventions to minimize cravings and the treatment of withdrawal symptoms associated with dependence [9]. Nicotine replacement therapies (NRT) in different formulations, such as inhalation, patches, gums, nasal sprays and lozenges, can be used for the treatment of withdrawal symptoms after smoking cessation. Since the nicotine concentration in NRT is low compared to tobacco, these therapies have a low addiction rate [3].

Amfebutamone (bupropion) represents the first non-nicotine drug used for the treatment of nicotine dependence. Amfebutamone is a nicotine receptor antagonist and inhibits the reuptake of epinephrine, dopamine and serotonin, thus reducing withdrawal symptoms [15-17]. Varenicline is a nicotine

Page 2/17 
receptor partial agonist that blocks nicotine receptors by binding into $a_{4} \beta_{2}$ nicotinic acetylcholine receptors and moderately releases dopamine, thus reducing the craving and withdrawal symptoms associated with an absence of nicotine [18].

Although most of the previous trials and systematic reviews supported the effectiveness of behavioural interventions [19, 20] for smoking cessation, the findings are less consistent for pharmacological interventions. To date, many trials and systematic reviews have been conducted to assess the effectiveness of smoking cessation interventions. Thus, a sound next step in providing evidence to healthcare decision-makers is a review of existing systematic reviews $[21,22]$. Therefore, in this umbrella review, we have assessed the effectiveness of different pharmacotherapies and the methodological quality of the included reviews.

\section{Objectives}

The current umbrella review synthesised findings of previous reviews conducted to evaluate the effects of pharmacotherapies for smoking cessation and assessed the consistency of conclusions among previous systematic reviews. This umbrella review summarized the effects of pharmacological interventions reported by each review of smoking cessation, specifically addressing the following objectives:

- To summarize existing systematic reviews that assessed the effects of pharmacological interventions for smoking cessation; and

- To assess the methodological quality of previously conducted systematic reviews

\section{Methods}

\section{Protocol registration and reporting of findings}

The protocol of this review followed the guidelines of Preferred Reporting Items for Systematic Review and Meta-analysis Protocols (PRISMA-P) [23]. The protocol was registered in PROSPERO (registration number CRD42017080906), available from http://www.crd.york.ac.uk/PROSPERO/display_record.php?ID=CRD42017080906. The findings of the systematic review were reported in accordance with the recommendation of Preferred Reporting Items for Systematic Review and Meta-Analysis (PRISMA) [24]. The PRISMA checklist is available as Additional File 1. The Joanna Briggs Institute Reviewers' Manual was also used to guide and organize the review processes [25].

\section{Inclusion and exclusion criteria}

Since the primary aim of the current umbrella review was to identify the effect of pharmacological interventions on smoking cessation, only reviews that include randomized control trials were reviewed. Since smoking cessation interventions are mostly targeted at adults aged 15 and over, in this umbrella review, we have included studies of young people and adults aged 15 and over who were smokers [26]. All systematic reviews that used randomized control trial studies designed to assess the effect of pharmacotherapy in any setting were included in this review. The umbrella review included only reviews for which the full text is available. The outcome variable measured in this study was smoking cessation. The control or comparison groups used were either standard care or placebo, no intervention. or alternative pharmacotherapy. The current review included only reviews that reported pooled effects of the included studies. The current review only included studies published in English.

If the review was an update of a previous review, the ost recent review data were included. Reviews that assessed combined pharmacotherapy and behavioural interventions were excluded unless the review reported the effect of pharmacotherapy separately, in which case the review was included. The summary of inclusion criteria based on population, intervention, comparator and outcome and study design (PICOS) is presented in Table 1.

\section{Information source and search strategy}

To trace related reviews, databases such as the Cochrane library, PubMed, MEDLINE, EMBASE, CINAHL, PsycINFO, Web of Science, Scopus and Google Scholar were used without limits on the publication period. Each database was searched up to September 2, 2019. Additional reviews were sought using the reference lists of the retrieved articles. Additional articles were traced from daily email alerts from the MEDLINE database throughout the review process. The search strategy was developed in consultation with a senior librarian (DB). Different keywords/search terms were used to access reviews from the database, including "smoking cessation", "smoking abstinence", "Pharmacotherapy", "Nicotine replacement therapy (NRT)", "bupropion", "Varenicline" "combination therapy", "non-nicotine drug", "nicotine receptor partial agonist", "meta-analysis", and "Systematic review". The search strategy for Medline is found in Additional File 2.

\section{Data collection processes}

Studies not fulfilling the inclusion criteria were first excluded by reading the title, and then the abstract of the articles. Full articles were then accessed and those articles not fitting the objectives of the review were excluded. The excluded studies were recorded along with the reason for exclusion at each stage. The JBI data abstraction format was used to extract information from the 
studies. Two authors (AM, AB) screen the titles and abstracts of all publications obtained by the search strategy, and assessed the full text of selected articles for inclusion and extracted and checked data independently. Discrepancies were resolved by discussion between the authors. The data extraction form was designed to extract data relating to the objectives of the study, study design, study inclusion and exclusion criteria, number of articles and participants included, participant characteristics, intervention, control, outcome and pooled effect, among others. The data extraction form is shown in Additional File 3.

Assessment of methodological quality

Methodological quality of the included reviews was assessed using the Assessment of Multiple Systematic Reviews 2 (an update of AMSTAR) tool, which contains 16 domains [27]. The tool includes 10 items from the original AMSTAR tool. Two items were created by splitting a single item from the original AMSTAR tool [28]. In total, four domains were added in AMSTAR 2 which were not found in the original tool. The response option for most domains consists of "yes" and "no" while some domains contain the third option "partial yes". AMSTAR has been shown to have good inter-rater reliability to assess the quality of systematic reviews. From the 16 AMSTAR tool items, 7 were critical domains upon which the quality rating of individual systematic reviews depends. Based on the overall score, the quality of each systematic review was rated as high, moderate, low and critically low. Table 2 presents the criteria to rate the quality of systematic reviews. The AMSTAR 2 checklist is found in Additional File 4 . Scores for each item were reported separately for each systematic review. The quality assessment of the included systematic review was conducted by two independent reviewers (AM, AB) and any disagreement between the two reviewers was resolved with discussion or the aid of another reviewer (CC). Studies were not excluded based on their quality, but the assessment serves to judge the strength of evidence generated by the included studies.

The following are items in AMSTAR 2 (The full version is found in additional file 4)

1. Did the research questions and inclusion criteria for the review include the components of PICO?

2. Did the report of the review contain an explicit statement that the review methods were established prior to the conduct of the review and did the report justify any significant deviations from the protocol?

3. Did the review authors explain their selection of the study designs for inclusion in the review?

4. Did the review authors use a comprehensive literature search strategy?

5. Did the review authors perform study selection in duplicate?

6. Did the review authors perform data extraction in duplicate?

7. Did the review authors provide a list of excluded studies and justify the exclusions?

8. Did the review authors describe the included studies in adequate detail?

9. Did the review authors use a satisfactory technique for assessing the risk of bias (RoB) in individual studies?

10. Did the review authors report on the sources of funding for the studies included in the review?

11. If meta-analysis was performed did the review authors use appropriate methods for statistical combination of results?

12. If meta-analysis was performed, did the review authors assess the potential impact of RoB in individual studies on the results of the meta-analysis or other evidence synthesis?

13. Did the review authors account for RoB in individual studies when interpreting/ discussing the results of the review?

14. Did the review authors provide a satisfactory explanation for, and discussion of, any heterogeneity observed in the results of the review?

15. If they performed quantitative synthesis did the review authors carry out an adequate investigation of publication bias (small study bias) and discuss its likely impact on the results of the review?

16. Did the review authors report any potential sources of conflict of interest, including any funding they received for conducting the review?

Data synthesis

In this review, a meta-analysis was not conducted because data from individual studies are likely to be represented more than once across the systematic reviews and this could likely lead to over- or underestimation of the true effect size [21]. The required information was collected using a pretested checklist based on the objectives of the review [29]. A narrative synthesis method was employed to show the effects of different pharmacotherapies on smoking cessation. The narrative presentation included the overall effect size reported by systematic review authors along with statistical heterogeneity and methodological quality. Evidence was summarized in a table to present the types of intervention, comparators, outcome measures, number of participants, number of included primary studies, and pooled results from each review, heterogeneity, and the review author's conclusions.

To calculate the degree of overlap, we calculated the Corrected Covered Area (CCA) by dividing the frequency of repeated occurrence of index publication in other reviews by the product of index publications and reviews, less the number of index publications. The CCA was rated as follows: CCA less than 5 was rated as slight overlap, 6-10 was considered a moderate overlap, 11-15 a high degree of overlap and greater than 15 as a very high degree of overlap [30].

Page $4 / 17$ 
$C A=\frac{\mathrm{N}-\mathrm{r}}{\mathrm{rc}-\mathrm{r}}$, where

$N$ is the number of included publications (including double counting);

$r$ is the number of rows (number of index publications)

$C$ is the number of column (number of reviews)

\section{Results}

The search identified 218 studies from a range of databases and other sources using comprehensive and sensitive search terms. After removing duplicates, 156 studies were assessed by reading their titles and abstracts, of which 136 studies were removed as they were not relevant to the review question. Finally, 20 full text articles were assessed, of which 10 studies were excluded. Reasons for study exclusion included combined intervention with behavioural therapy [31-33], measured cost-effectiveness of pharmacological smoking cessation therapies [34], pooled effect not provided [35-37], review not published in English [38], inclusion of non-randomized controlled trials in the review [39], and inclusion of study participants under the age of 15 [40]. The PRISMA flow diagram is depicted in Figure 1.

\section{Characteristics of included reviews}

Table 3 presents the detailed characteristics of the included systematic reviews. Of the nine included reviews, three assessed the effectiveness of nicotine replacement therapy [41-43], two assessed the effect of multiple pharmacotherapy [44, 45], one compared combination therapy (NRT+ varenicline vs varenicline alone) [46], one compared opioid antagonists to placebo or an alternative therapy [47], one evaluated the effectiveness of silver acetate products (gum, lozenge, spray) [48], one compared the combined effect of nicotine replacement therapy of different formulations [49] and one assessed the effectiveness of cytisine [50]. In total, 149 trials were included in 10 systematic reviews (mean per review: 14.2; range: 2-86). The calculated corrected covered area (CCA) was $8.3 \%$, which indicated moderate overlaps of primary publication in the included reviews. The included reviews consisted of a total of 67,588 study participants (mean per review: 6758.8). However, data from individual studies are likely to be represented more than once across the systematic reviews. Of the included reviews, two were Cochrane reviews. Six studies included in their reviews only studies that verified smoking cessation/abstinence using biochemical methods, while four included studies which used both self-reported and biochemical techniques (Table 4).

\section{Methodological quality of included reviews}

The reviews were assessed for methodological quality using the AMSTAR 2 quality appraisal tool for systematic reviews. Table 5 presents the score of each item for specific systematic reviews. Based on the AMSTAR 2 rating, one review scored high quality, two scored moderate quality, four scored low quality, and three scored critically low quality. Among the 16 AMSTAR 2 domains assessed except for two reviews, all the other reviews failed to develop or report the presence of written protocol (item 2). Of the ten reviews included only one review reported on the sources of funding for the studies included in the review (item 10). On the other hand, all reviews satisfied items related to the selection of the study designs for inclusion in the review (item 3 ) and report potential sources of conflict of interest and funding (item16).

\section{The effectiveness of pharmacological interventions}

\section{Nicotine replacement therapy}

In one review, which included 11 randomized controlled trials involving 1,808 study participants, researchers found that pharmacotherapy significantly increased the smoking cessation rate compared to the placebo group (RR $=1.88,95 \% \mathrm{Cl}: 1.35,2.57)$ at 6 weeks to 18 -months follow-up. Likewise the pooled effect from a sub-analysis of three trials using only NRT indicated a significant positive effect on smoking cessation rate $(\mathrm{RR}=7.74,95 \% \mathrm{Cl}$ : $3.00,19.94 ; 3$ studies, 635 participants) [44]. In the quality appraisal, this paper was scored as having 'high' methodological quality.

In a review of seven studies ('moderate' methodological quality review), Moore et al. found that NRT increased smoking cessation for at least six months compared with the placebo ( $\mathrm{RR}=2.06,95 \% \mathrm{Cl}: 1.34,3.15 ; 5$ studies) [43]. Another study assessing the pooled effect from 12 randomized controlled trials ('low' methodological quality review) supported the favourable effect of NRT on sustaining smoking cessation beyond 12 months compared to a placebo $(\mathrm{OR}=1.99,95 \% \mathrm{Cl}: 1.50,2.64)[41]$.

The pooled effect from a review that included 70 trials $(n=28,343)$ found that the odds of smoking cessation at one year were higher among participants using NRT compared to the control group (OR $=1.71,95 \%, \mathrm{Cl}: 1.55,1.88)$ [45]. In this review, the finding was consistent across all NRT formulations (gum, patch). In addition, the pooled effect of 59 trials $(n=25,294)$ demonstrated that NRT provided support for the efficacy of smoking cessation in the short-term follow-up (3 months) compared to the control group (OR $=1.98,95 \% \mathrm{Cl}$ : $1.77,2.21)[45]$. In the quality appraisal, this review scored a 'critically low' methodological quality. Conversely, a review by Lindson et al ('critically low' methodological quality review) that included eight studies and 2,813 participants found no significant effects of NRT over placebo for the treatment of smoking cessation in the short-term follow-up (4 to 12 weeks) $(\mathrm{RR}=1.05,95 \% \mathrm{Cl}: 0.92,1.19)$ and long-term follow-up (6 to 12 months) $(\mathrm{RR}=1.16,95 \% \mathrm{Cl}: 0.97,1.38)[42]$. 
The pooled effect of 12 trials including 5,228 participants showed bupropion was more effective for smoking cessation compared to the control group at the one-year follow-up $(\mathrm{OR}=1.56,95 \% \mathrm{Cl}: 1.10,2.21)$. Moreover, bupropion was more effective than placebo at the 3-month follow-up $(\mathrm{OR}=2.13$, $95 \%$ Cl: $1.72,2.64 ; 11$ trials)[45]. The pooled effect of 4 studies $(n=2,528)$ found that varenicline was effective for smoking cessation compared to placebo both at long-term follow-up ( 1 year) $(\mathrm{OR}=2.96,95 \% \mathrm{Cl}: 2.12,4.12)$ and short-term follow-up evaluation ( 3 months) $(\mathrm{OR}=3.75,95 \% \mathrm{Cl}$ : 2.65 , 5.30). Similarly, varenicline was more effective than bupropion at one year follow-up (OR $=1.58,95 \% \mathrm{Cl}$ : $1.22,2.05 ; 3$ trials) and three-month follow-up (OR $=1.61,95 \% \mathrm{Cl}: 1.16,2.21 ; 3$ trials) $[45]$.

\section{Combination therapy}

Chang et al ('low' methodological quality review) found that study participants on a combined regimen (NRT and non-NRT) were more likely to abstain from smoking compared with those in a non-NRT (varenicline) only treatment group, both during the short-term (measured at 4-12 months before treatment completion; $\mathrm{OR}=1.50,95 \% \mathrm{Cl}: 1.14,1.97 ; 3$ trials) and long-term (measured at the end of 2-24 months after treatment completion; OR $=1.62$, 95\% Cl: 1.18, 2.23; 2 trials) [46]. Combining naltrexone and NRT did not favour smoking cessation compared to the placebo group based on the 6month reported abstinence rate $(\mathrm{RR}=0.95,95 \% \mathrm{Cl}: 0.70,1.30 ; 4$ studies $)$ [47].

In a 'critically low' methodological quality review that included 2,204 study participants from 5 trials, a combination therapy of nicotine replacement patches with other nicotine formulation drugs (nicotine gum or nicotine inhaler or nicotine nasal spray) was found to be more effective than monotherapy at 3 months ( $R R=1.42,95 \% \mathrm{Cl}: 1.21,1.67 ; 4$ trials), at 6 months ( $\mathrm{RR}=1.54,95 \% \mathrm{Cl}: 1.19,2.00 ; 4$ trials) and at the 12 -month follow-up (RR $=1.58,95 \% \mathrm{Cl}: 1.25,1.99 ; 4$ trials) [49].

\section{Other therapies}

The pooled effect of a study including eight randomized control trials with 1,213 study participants identified that opioid antagonist therapy had no effect on smoking cessation rate based on the 6-month reported abstinence rate (RR $=0.97 ; 95 \% \mathrm{Cl}$ : $0.76,1.24)$. Five studies that assessed the effect of naltrexone (long-acting form of opioid antagonist) compared to placebo also showed no significant effect on smoking abstinence rate (RR = 1.00 ; $95 \% \mathrm{Cl}: 0.66,1.51)[47]$. In the quality appraisal, this review was scored as having 'low' methodological quality. Silver nitrate was not effective for smoking cessation compared to placebo at a minimum of 6-month follow-up ( $\mathrm{RR}=1.04,95 \% \mathrm{Cl}$ : $0.69,1.57 ; 2$ trials) [48]. This review was ranked as having a 'low' methodological quality. A review that includes 7 trials (4020 participants) found that cytisine was effective for smoking cessation at 3weeks to 2 years of follow-up ( $R R=1.57,95 \% \mathrm{Cl}: 1.42$ to 1.74 ) compared to placebo. The pooled effect of two high-quality reviews also confirmed the effectiveness of cytisine for smoking cessation at 6 months of follow-up compared to placebo (RR $=3.29$. 95\% Cl: 1.84 to 5.90$)$ [50]. This review was ranked as having a 'moderate' methodological quality.

\section{Discussion}

In this umbrella review, we aimed to assess the effect of different pharmacotherapies on smoking cessation. Most of the included reviews found supportive evidence for NRT being an efficacious treatment for withdrawal symptoms associated with nicotine dependence. Nicotine replacement therapy in different formulations are used as a first line drug for the treatment of nicotine addiction in many settings [51]. Non-nicotine pharmacotherapy such as bupropion varenicline and cytisine were also found to be effective for smoking cessation. Reviews also revealed that the combination of NRT and varenicline was more effective for smoking cessation compared with varenicline alone. Moreover, a combination of different formulations of NRT (gum, nasal spray) with nicotine patches was more effective than nicotine patch monotherapy. Evidence suggests that the use of other formulations of NRT (gum, inhaler, spray) in combination with nicotine patches helps to supplement blood nicotine concentrations at times of craving or risk of smoking relapse [51]. NRT, bupropion and varenicline are second-line drugs approved by the US Food and Drug Administration and other countries for the treatment of smoking cessation [52]. Some randomized trial studies reported the superiority of cytisine for smoking cessation compared to NRT [53]. Cytisine is cheapest compared to smoking cessation drugs such as NRT, bupropion, and varenicline [54].

The severity of nicotine dependence is one factor that can affect the effectiveness of pharmacotherapies for smoking cessation. Some researchers found that the rate of smoking cessation was lower among study participants who smoked a greater number of cigarettes per day compared to those who smoked fewer cigarettes per day $[9,55]$. The level of treatment compliance is also an important factor in attaining and sustaining smoking abstinence $[12,56]$.

Findings from previous systematic reviews and reviews of reviews demonstrated the effectiveness of behavioural interventions for smoking cessation $[19,20]$. Moreover, studies have found the effectiveness of combined pharmacological and behavioural interventions for smoking cessation [57]. In a systematic review of the reviews, researchers found that compared to NRT alone, a combination of non-pharmacological interventions such as brief counselling and pharmacotherapy has been more effective for smoking cessation [58]. Moreover, behavioural interventions have been recommended to prevent relapse and to sustain smoking cessation achieved by pharmacotherapy [59]. Therefore, combining counselling and pharmacotherapy could be more efficacious for smoking cessation. A Cochrane systematic review with low-quality evidence that include two primary randomized controlled trials found that e-cigarette use helped with smoking cessation [60]. However, the findings regarding the effectiveness of e-cigarette for smoking cessation were inconsistent. 
Overall, the quality of the systematic reviews included in the current umbrella review was rated as 'critically low' to 'high. The majority of the included reviews scored 'low' and 'critically low' methodological quality. All of the reviews included in the current umbrella review have published before the development of the updated AMSTAR tool (AMSTAR 2). Therefore, the authors of the reviews could not be able to follow the AMSTAR 2 checklist in conducting the reviews. Future reviews should follow the AMSTAR 2 checklist and guideline to produce quality evidence that informs policy. The majority of the reviews addressed item 11 (Appropriateness of meta-analytical methods). In the previous systematic review of reviews, these items were also well addressed by review authors [61-63]. Duplicate selection of articles to be included in a systematic review can decrease the chance of missing articles. In the current review, item 5 ("Duplicate study selection) and item 6 (Duplicate data extraction") was well addressed by most of the included reviews.

Formulating a review protocol is an important step prior to conducting a systematic review. This is in order to determine whether the review was conducted as per the plan and if not, to justify reasons for amending the plan $[64,65]$. In almost all of the included reviews, no statement about the protocol registration and/or publication was stated under the second criteria ("Was an "a priori" design provided?"). This finding was consistent with a previous review undertaking a quality assessment of systematic reviews in paediatric surgery [66]. Clinicians and decision-makers need to assure themselves that the basic approaches and methods used to collect and combine the findings of individual studies are relevant and sound before using the evidence for patient care and policy development. The observed poor methodological quality demonstrated the importance of encouraging review authors to adhere to guidelines that advance excellence in conducting systematic reviews. Improving the methodological quality of systematic reviews is fundamental to precisely inform clinical decision-making [67].

There are several limitations of this review that should be acknowledged. First, the timing of the outcome measure was not consistent across the included reviews. Some of the studies measured short-term effects or long-term effects, while others measured both. Since the data were not retrieved from the primary studies, we were restricted by the evidence reported by the review authors with respect to aspects including the explanation of the intervention, method, outcome, and conclusions. Despite duplicate study selection, subjectivity in data extraction and quality appraisal are not totally avoidable. Another limitation of this review was the restriction of the review to articles published in English. Despite these limitations, this umbrella review considered only systematic reviews that included primary studies with a randomized controlled trial design. Article selection, data abstraction, and quality appraisal were also conducted in duplicate, minimizing selection bias.

\section{Conclusions}

In this review, NRT, bupropion varenicline and cytisine were found to be effective for smoking cessation. Likewise, the combination of a nicotine patch with other nicotine formulations and combination of nicotine with non-nicotine pharmacotherapy were found to be effective for smoking cessation compared to nicotine monotherapy. Silver nitrate was not found to be effective for smoking cessation. The quality of the reviews included in this umbrella review ranges from high to critically low. We recommend future studies and subsequent reviews to identify other factors that could affect the effectiveness of pharmacotherapy for smoking cessation. We also recommend review authors adopt and follow the AMSTAR 2 tool to improve the methodological and reporting quality of systematic reviews. The findings of the current review will improve clinical decision-making and can be used as a baseline for future studies.

\section{Abbreviations}

NRT: Nicotine replacement therapy; COPD: Chronic obstructive pulmonary disease; PRISMA: Preferred reporting items for systematic review and metaanalysis; PROSPERO: International prospective register of systematic reviews; AMSTAR: Assessment of multiple systematic reviews; RR: Relative risk; OR: Odds ratio.

\section{Declarations}

\section{Acknowledgement}

We would like to acknowledge senior librarian at the University of Newcastle, Debbie Booth for the assistance in developing the search strategy. We are grateful to Natalia Soeters for language support.

\section{Funding}

This study had no funding source.

\section{Availability of data}

Not applicable

\section{Authors' contributions}

AS developed the review protocol and $C C, D L$ and $E H$ reviewed the protocol. AS and AB identified, screened and extracted data from articles. AS and AB conducted quality assessment of the articles. AS wrote the findings. CC, DL and EH revised and reviewed the articles. All authors approved the final 
submission of the paper.

\section{Ethics approval and consent for participants}

Not applicable

Consent for publication: Not applicable

Competing interests: The authors declare that they have no competing interests.

\section{References}

1. Ng M, Freeman MK, Fleming TD, Robinson M, Dwyer-Lindgren L, Thomson B, et al. Smoking prevalence and cigarette consumption in 187 countries, 1980-2012. Jama. 2014;311(2):183-92. doi:10.1001/jama.2013.284692.

2. National Institute on Drug Abuse. Cigarettes and Other Tobacco Products. 2017. https://www.drugabuse.gov/publications/drugfacts/cigarettesother-tobacco-products. Accessed 9 Jan 2018.

3. US Department of Health and Human service. Are There Effective Treatments for Tobacco Addiction? . National institute of health; 2016.

4. World Health Organization. WHO global report on trends in prevalence of tobacco smoking 2015: World Health Organization; 2015. http://apps.who.int/iris/bitstream/10665/156262/1/9789241564922_eng.pdf. Accessed 18 Sept 2019.

5. S. Department of Health and Human Services. How Tobacco Smoke Causes Disease: The Biology and Behavioral Basis for Smoking-Attributable Disease: A Report of the Surgeon General. Atlanta, GA: U.S. Department of Health and Human Services, Centers for Disease Control and Prevention, National Center for Chronic Disease Prevention and Health Promotion, Office on Smoking and Health, 2010. https://www.ncbi.nIm.nih.gov/books/NBK53017/. Accessed 2 June 2019.

6. US Department of Health and Human Services. The health consequences of involuntary exposure to tobacco smoke: a report of the Surgeon General. 2006. https://www.barnesandnoble.com/w/the-health-consequences-of-involuntary-exposure-to-tobacco-smoke-department-of-humanservices/1112109451. Accessed 9 June 2019.

7. Öberg M, Jaakkola MS, Woodward A, Peruga A, Prüss-Ustün A. Worldwide burden of disease from exposure to second-hand smoke: a retrospective analysis of data from 192 countries. The lancet. 2011;377(9760):139-46. doi:10.1016/S0140-6736(10)61388-8.

8. Rehm J, Taylor B, Room R. Global burden of disease from alcohol, illicit drugs and tobacco. Drug and alcohol review. 2006;25(6):503-13. doi:10.1080/09595230600944453.

9. Jiloha R. Pharmacotherapy of smoking cessation. Indian journal of psychiatry. 2014;56(1):87. doi:10.1080/09595230600944453.

10. Taylor Jr DH, Hasselblad V, Henley SJ, Thun MJ, Sloan FA. Benefits of smoking cessation for longevity. American journal of public health. 2002;92(6):990-6. doi:10.4103/0019-5545.124726.

11. General US. The health benefits of smoking cessation. Washington: Department of Health and Human Services. 1990.https://www.cdc.gov/mmwr/preview/mmwrhtml/00001778.htm. Accessed 8 August 2019.

12. Kahler CW, Spillane NS, Metrik J, Leventhal AM, Monti PM. Sensation seeking as a predictor of treatment compliance and smoking cessation treatment outcomes in heavy social drinkers. Pharmacology Biochemistry and Behavior. 2009;93(3):285-90. doi:10.1016/j.pbb.2009.01.003.

13. Eddy DM, Peskin B, Shcheprov A, Pawlson G, Shih S, Schaaf D. Effect of smoking cessation advice on cardiovascular disease. American Journal of Medical Quality. 2009;24(3):241-9. doi:10.1177/1062860609332509.

14. Costa e Silva Vd. Tools for advancing tobacco control in the XXIst century: policy recommendations for smoking cessation and treatment of tobacco dependence: tools for public health: World Health Organization; 2003. https://www.cabdirect.org/cabdirect/abstract/20043140908. Accessed 9 Jun 2018.

15. Damaj MI, Slemmer J, Carroll F, Martin B. Pharmacological characterization of nicotine's interaction with cocaine and cocaine analogs. Journal of Pharmacology and Experimental Therapeutics. 1999;289(3):1229-36.http://jpet.aspetjournals.org/content/289/3/1229.short. Accessed 18 Sept 2019.

16. Covey LS, Sullivan MA, Johnston JA, Glassman AH, Robinson MD, Adams DP. Advances in non-nicotine pharmacotherapy for smoking cessation. Drugs. 2000;59(1):17-31. doi:10.2165/00003495-200059010-00003.

17. Roddy E. ABC of smoking cessation: bupropion and other non-nicotine pharmacotherapies. BMJ: British Medical Journal. $2004 ; 328(7438): 509$. doi:10.1136/bmj.328.7438.509.

18. Mihalak KB, Carroll FI, Luetje CW. Varenicline is a partial agonist at a4 32 and a full agonist at a7 neuronal nicotinic receptors. Molecular pharmacology. 2006;70(3):801-5. doi:10.1124/mol.106.025130.

19. Mottillo S, Filion KB, Belisle P, Joseph L, Gervais A, O'Loughlin J, et al. Behavioural interventions for smoking cessation: a meta-analysis of randomized controlled trials. European heart journal. 2008;30(6):718-30. doi:10.1093/eurheartj/ehn552

20. Lancaster T, Stead LF. Individual behavioural counselling for smoking cessation. Cochrane database of systematic reviews. 2017(3). doi:10.1002/14651858.CD001292. 
21. Aromataris E, Fernandez R, Godfrey CM, Holly C, Khalil H, Tungpunkom P. Summarizing systematic reviews: methodological development, conduct and reporting of an umbrella review approach. International journal of evidence-based healthcare. 2015;13(3):132-40.

doi:10.1097/XEB.0000000000000055

22. Ioannidis JP. Integration of evidence from multiple meta-analyses: a primer on umbrella reviews, treatment networks and multiple treatments meta-analyses. Cmaj. 2009;181(8):488-93. doi: 10.1503/cmaj.081086.

23. Shamseer L, Moher D, Clarke M, Ghersi D, Liberati A, Petticrew M, et al. Preferred reporting items for systematic review and meta-analysis protocols (PRISMA-P) 2015: elaboration and explanation. BMJ (Clinical research ed). 2015;349:g7647. doi:10.1136/bmj.g7647.

24. Moher D, Liberati A, Tetzlaff J, Altman DG, Group P. Preferred reporting items for systematic reviews and meta-analyses: the PRISMA statement. PLoS med. 2009;6(7):e1000097. doi:10.1371/journal.pmed.1000097.

25. Institute JB. Joanna Briggs Institute reviewers' manual: 2014 edition. Australia: The Joanna Briggs Institute. 2014.https://nursing.Isuhsc.edu/JBI/docs/ReviewersManuals/Umbrella Reviews.pdf. Accessed 9 Jan 2018.

26. Zwar N, Mendelsohn C, Richmond . Tobacco smoking: options for helping smokers to quit. 2014. https://www.racgp.org.au/afp/2014/june/helping-smokers-quit/.

27. Shea BJ, Reeves BC, Wells G, Thuku M, Hamel C, Moran J, et al. AMSTAR 2: a critical appraisal tool for systematic reviews that include randomised or non-randomised studies of healthcare interventions, or both. bmj. 2017;358:j4008. doi: 10.1136/bmj.j4008.

28. Shea BJ, Grimshaw JM, Wells GA, Boers M, Andersson N, Hamel C, et al. Development of AMSTAR: a measurement tool to assess the methodological quality of systematic reviews. BMC medical research methodology. 2007;7(1):10. doi:10.1186/1471-2288-7-10.

29. Higgins JP, Green S. Cochrane handbook for systematic reviews of interventions: John Wiley \& Sons; 2011. http://handbook-5-1.cochrane.org/.

30. Pieper D, Antoine S-L, Mathes T, Neugebauer EA, Eikermann M. Systematic review finds overlapping reviews were not mentioned in every other overview. Journal of clinical epidemiology. 2014;67(4):368-75. https://doi.org/10.1016/j.jclinepi.2013.11.007.

31. Windle SB, Filion KB, Mancini JG, Adye-White L, Joseph L, Gore GC, et al. Combination therapies for smoking cessation: a hierarchical Bayesian meta-analysis. American journal of preventive medicine. 2016;51(6):1060-71. doi: 10.1016/j.amepre.2016.07.011.

32. Stead LF, Koilpillai P, Fanshawe TR, Lancaster T. Combined pharmacotherapy and behavioural interventions for smoking cessation. Cochrane Database Syst Rev. 2016;3:CD008286. doi:10.1002/14651858.CD008286.

33. Stanton A, Grimshaw G. Tobacco cessation interventions for young people. The Cochrane Library. 2013. doi:10.1002/14651858.CD003289.

34. Aumann I, Rozanski K, Damm K, Graf vdSJ. Cost-Effectiveness of Pharmacological Smoking Cessation Therapies-A Systematic Literature Review. Gesundheitswesen (Bundesverband der Arzte des Offentlichen Gesundheitsdienstes (Germany)). 2016;78(10):660-71. doi:10.1055/s-00351548852.

35. Schepis TS, Rao U. Smoking cessation for adolescents: a review of pharmacological and psychosocial treatments. Current Drug Abuse Reviews. 2008;1(2):142-55. doi:10.2174/1874473710801020142

36. King JL, Pomeranz JL, Merten JW. A systematic review and meta-evaluation of adolescent smoking cessation interventions that utilized nicotine replacement therapy. Addict Behav. 2016;52:39-45. doi: 10.1016/j.addbeh.2015.08.007.

37. Cox LS, Okuyemi K, Choi WS, Ahluwalia JS. A review of tobacco use treatments in US ethnic minority populations. American Journal of Health Promotion. 2011;25(5_suppl):S11-S30. doi:10.4278/ajhp.100610-LIT-177.

38. Wu C-Y, Wang H-L, Chen Y-L, Wu B-R, Chen T-J, Pan A-W. Randomized controlled trials for smoking cessation: a systematic review. Taiwan Gong Gong Wei Sheng Za Zhi. 2014;33(5):470.

39. Cawkwell PB, Blaum C, Sherman SE. Pharmacological smoking cessation therapies in older adults: a review of the evidence. Drugs \& aging. 2015;32(6):443-51. doi: 10.1007/s40266-015-0274-9.

40. Kim Y, Myung S-K, Jeon Y-J, Lee E-H, Park C-H, Seo HG, et al. Effectiveness of pharmacologic therapy for smoking cessation in adolescent smokers: Meta-analysis of randomized controlled trials. American Journal of Health-System Pharmacy. 2011;68(3):219-26. doi: 10.2146/ajhp100296.

41. Etter J-F, Stapleton JA. Nicotine replacement therapy for long-term smoking cessation: a meta-analysis. Tobacco control. 2006;15(4):280-5. doi:10.1136/tc.2005.015487.

42. Lindson N, Aveyard P. An updated meta-analysis of nicotine preloading for smoking cessation: investigating mediators of the effect. Psychopharmacology. 2011;214(3):579-92. doi: 10.1007/s00213-010-2069-3.

43. Moore D, Aveyard P, Connock M, Wang D, Fry-Smith A, Barton P. Effectiveness and safety of nicotine replacement therapy assisted reduction to stop smoking: systematic review and meta-analysis. Bmj. 2009;338:b1024. doi: 10.1136/bmj.b1024.

44. Apollonio D, Philipps R, Bero L. Interventions for tobacco use cessation in people in treatment for or recovery from substance use disorders. The Cochrane library. 2016. doi: 10.1002/14651858.CD010274.pub2

45. Wu P, Wilson K, Dimoulas P, Mills EJ. Effectiveness of smoking cessation therapies: a systematic review and meta-analysis. BMC Public Health. 2006;6(1):300. doi: 10.1186/1471-2458-6-300.

46. Chang P-H, Chiang C-H, Ho W-C, Wu P-Z, Tsai J-S, Guo F-R. Combination therapy of varenicline with nicotine replacement therapy is better than varenicline alone: a systematic review and meta-analysis of randomized controlled trials. BMC public health. 2015;15(1):689. doi:

Page 9/17 
10.1186/s12889-015-2055-0.

47. David SP, Chu IM, Lancaster T, Stead LF, Evins AE, Prochaska JJ. Systematic review and meta-analysis of opioid antagonists for smoking cessation. BMJ open. 2014;4(3):e004393. doi: 10.1136/bmjopen-2013-004393.

48. Lancaster T, Stead LF. Silver acetate for smoking cessation. The Cochrane Library. 2012. doi: 10.1002/14651858.CD000191.pub2.

49. Shah SD, Wilken LA, Winkler SR, Lin SJ. Systematic review and meta-analysis of combination therapy for smoking cessation. Journal of the American Pharmacists Association: JAPhA. 2008;48(5):659-65. doi: 10.1331/JAPhA.2008.07063.

50. Hajek P, McRobbie H, Myers K. Efficacy of cytisine in helping smokers quit: systematic review and meta-analysis. Thorax. 2013;68(11):1037-42. doi: 10.1136/thoraxjnl-2012-203035.

51. McDonough M. Update on medicines for smoking cessation. Australian prescriber. 2015;38(4):106. doi:10.18773/austprescr.2015.038.

52. Jaén CR, Benowitz NL, Curry SJ, Parsippany N, Kottke TE, Mermelstein RJ, et al. A clinical practice guideline for treating tobacco use and dependence: 2008 update. Am J Prev Med. 2008;35(2):158-76. doi: 10.1016/j.amepre.2008.04.009.

53. Walker N, Howe C, Glover M, McRobbie H, Barnes J, Nosa V, et al. Cytisine versus nicotine for smoking cessation. New England Journal of Medicine. 2014;371(25):2353-62. doi: 10.1056/NEJMoa1407764.

54. Leaviss J, Sullivan W, Ren S, Everson-Hock E, Stevenson M, Stevens JW, et al. What is the clinical effectiveness and cost-effectiveness of cytisine compared with varenicline for smoking cessation? A systematic review and economic evaluation. 2014. doi: 10.3310/hta18330.

55. Argüder E, Karalezli A, Hezer H, Kılıç H, Er M, Hasanoğlu HC, et al. Sigara bırakma başarısını etkileyen faktörler. Tur Toraks Derg. 2013;14:81-7. doi:10.5152/ttd.2013.18.

56. Costa e Silva Vd. Tools for advancing tobacco control in the XXIst century: policy recommendations for smoking cessation and treatment of tobacco dependence: tools for public health: World Health Organization;

2003.http://www.who.int/tobacco/resources/publications/en/intro_chapter3.pdf. Accessed 9 June 2018.

57. Stead LF, Koilpillai P, Fanshawe TR, Lancaster T. Combined pharmacotherapy and behavioural interventions for smoking cessation. Cochrane Database Syst Rev. 2016;3:CD008286. doi:10.1002/14651858.CD008286.

58. Schmelzle J, Rosser WW, Birtwhistle R. Update on pharmacologic and nonpharmacologic therapies for smoking cessation. Canadian Family Physician. 2008;54(7):994-9. https://www.cfp.ca/content/54/7/994

59. Rigotti NA, Regan S, Levy DE, Japuntich S, Chang Y, Park ER, et al. Sustained care intervention and postdischarge smoking cessation among hospitalized adults: a randomized clinical trial. JAMA. 2014;312(7):719-28. doi: 10.1001/jama.2014.9237.

60. Hartmann-Boyce J, McRobbie H, Bullen C, Begh R, Stead LF, Hajek P. Electronic cigarettes for smoking cessation. Cochrane Database of Systematic Reviews. 2016(9). doi: 10.1002/14651858.CD010216.

61. Kowalczuk M, Adamich J, Simunovic N, Farrokhyar F, Ayeni OR. Methodological quality of systematic reviews addressing femoroacetabular impingement. Knee Surgery, Sports Traumatology, Arthroscopy. 2015;23(9):2583-9. doi: 10.1007/s00167-014-3151-x

62. Sorgente A, Pietrabissa G, Manzoni GM, Re F, Simpson S, Perona S, et al. Web-based interventions for weight loss or weight loss maintenance in overweight and obese people: a systematic review of systematic reviews. Journal of medical Internet research. 2017;19(6). doi: 10.2196/jmir.6972.

63. Pussegoda K, Turner L, Garritty C, Mayhew A, Skidmore B, Stevens A, et al. Systematic review adherence to methodological or reporting quality. Systematic reviews. 2017;6(1):131. doi:10.1186/s13643-017-0527-2.

64. Schlosser R. Appraising the quality of systematic reviews. Technical Brief No. 17. FOCUS: A publication of the National Center for the Dissemination of Disability Research. 2007. https://ktdrr.org/ktlibrary/articles_pubs/ncddrwork/focus/focus17/. Accessed 3 Oct 2019

65. Fusar-Poli P, Radua J. Ten simple rules for conducting umbrella reviews. Evidence-based mental health. 2018;21(3):95-100. doi: 10.1136/ebmental-2018-300014.

66. Cullis PS, Gudlaugsdottir K, Andrews J. A systematic review of the quality of conduct and reporting of systematic reviews and meta-analyses in paediatric surgery. PloS one. 2017;12(4):e0175213. doi: 10.1371/journal.pone.0175213.

67. Yao X, Vella E, Brouwers M. How to conduct a high-quality systematic review on diagnostic research topics. Surgical oncology. 2018;27(1):70-5. doi: 10.1016/j.suronc.2017.11.010.

\section{Tables}

Table 1: Population, intervention, comparator, outcome and study design (PICOS) elements 


\begin{tabular}{l|l|}
\hline $\begin{array}{c}\text { PICOS } \\
\text { elements }\end{array}$ & \multicolumn{1}{|c|}{ Criteria } \\
\hline Population & Young people and adults aged 15 years and over who were smokers. \\
\hline Intervention & $\begin{array}{l}\text { Reviews assessed only the effect of pharmacotherapy on smoking cessation were included. Reviews, which } \\
\text { assessed combined pharmacotherapy and behavioural interventions, were excluded. }\end{array}$ \\
\hline Comparator & The control may be either standard care or placebo, no intervention. or alternative pharmacotherapy. \\
\hline $\begin{array}{l}\text { Outcome } \\
\begin{array}{l}\text { Study } \\
\text { design }\end{array}\end{array}$ & The outcome variable measured in this study was smoking cessation. \\
\hline
\end{tabular}

Table 2: Quality rating criteria

\begin{tabular}{|c|c|c|}
\hline $\begin{array}{l}\text { luality } \\
\text { ating }\end{array}$ & Criteria & AMSTAR 2 critical domains \\
\hline [igh & No or one non-critical weakness & \multirow{4}{*}{$\begin{array}{l}\text { Protocol registered before commencement of the review } \\
\text { (item 2) } \\
\text { - Adequacy of the literature search (item 4) } \\
\text { Justification for excluding individual studies (item 7) } \\
\text { Risk of bias from individual studies being included in the } \\
\text { review (item 9) } \\
\text { Appropriateness of meta-analytical methods (item 11) } \\
\text { Consideration of risk of bias when interpreting the results } \\
\text { of the review (item 13) } \\
\text { Assessment of presence and likely impact of publication } \\
\text { bias (item 15) }\end{array}$} \\
\hline Ioderate & More than one non-critical weakness & \\
\hline ow & $\begin{array}{l}\text { One critical flaws with or without non-critical } \\
\text { weakness }\end{array}$ & \\
\hline ritically & $\begin{array}{l}\text { More than one critical flaw with or without } \\
\text { non-critical weakness }\end{array}$ & \\
\hline
\end{tabular}




\begin{tabular}{|c|c|c|c|c|c|c|}
\hline $\begin{array}{l}\text { zw } \\
\text { ors } \\
\text { rear }\end{array}$ & $\begin{array}{l}\text { Number of trials } \\
\text { included/number of } \\
\text { participants }\end{array}$ & $\begin{array}{l}\text { Review } \\
\text { questions/ } \\
\text { objectives }\end{array}$ & $\begin{array}{l}\text { Outcome } \\
\text { measures/intervention }\end{array}$ & $\begin{array}{l}\text { Inclusion } \\
\text { criteria }\end{array}$ & Summary findings & $\begin{array}{l}\text { Authors } \\
\text { comments }\end{array}$ \\
\hline $\begin{array}{l}\text { lonio } \\
\text {, }\end{array}$ & $\begin{array}{l}35 \text { RCT, (11 } \\
\text { assessed } \\
\text { pharmacotherapy)/ } \\
5796 \text { (1808 } \\
\text { pharmacotherapy) }\end{array}$ & $\begin{array}{l}\text { To assess } \\
\text { whether } \\
\text { interventions for } \\
\text { smoking } \\
\text { cessation are } \\
\text { related with } \\
\text { smoking } \\
\text { abstinence for } \\
\text { people in } \\
\text { concurrent } \\
\text { treatment for or } \\
\text { in recovery from } \\
\text { alcohol } \\
\text { dependence }\end{array}$ & $\begin{array}{l}\text { smoking abstinence/ } \\
\text { pharmacotherapy of } \\
\text { NRT and non-NRT }\end{array}$ & $\begin{array}{l}\text { No } \\
\text { exclusions } \\
\text { based on } \\
\text { language of } \\
\text { publication } \\
\text { or } \\
\text { publication } \\
\text { status } \\
\text { The study } \\
\text { included } \\
\text { adults aged } \\
15 \text { years } \\
\text { and over } \\
\text { who were } \\
\text { treated for } \\
\text { alcohol } \\
\text { dependence }\end{array}$ & $\begin{array}{l}\text { Pharmacotherapy } \\
\text { increased } \\
\text { smoking } \\
\text { abstinence (RR = } \\
\text { 1.88, 95\% CI: } \\
\text { 1.35, 2.57; } 11 \\
\text { studies, 1,808 } \\
\text { participants, low } \\
\text { quality evidence) } \\
\text { When the } \\
\text { analysis was } \\
\text { restricted to } \\
\text { those studies } \\
\text { evaluating only } \\
\text { NRT, the } \\
\text { treatment effect } \\
\text { remained } \\
\text { significant (RR = } \\
\text { 7.74, 95\% CI: } \\
\text { 3.00, 19.94; } 3 \\
\text { studies, 635 } \\
\text { participants) }\end{array}$ & $\begin{array}{l}\text { Overall, the } \\
\text { results suggest } \\
\text { that smoking } \\
\text { cessation } \\
\text { interventions } \\
\text { incorporating } \\
\text { pharmacotherapy } \\
\text { should be } \\
\text { incorporated into } \\
\text { clinical practice }\end{array}$ \\
\hline $\begin{array}{l}\mathrm{lg} \text { et } \\
015\end{array}$ & $\begin{array}{l}3 \text { trials/ } 904 \\
\text { participants }\end{array}$ & $\begin{array}{l}\text { To examine the } \\
\text { effectiveness of } \\
\text { varenicline } \\
\text { combined with } \\
\text { NRT for smoking } \\
\text { cessation }\end{array}$ & $\begin{array}{l}\text { Smoking abstinence } \\
\text { rates/ Combination } \\
\text { therapy (NRT+ } \\
\text { varenicline) vs. } \\
\text { varenicline + placebo } \\
\text { patch }\end{array}$ & $\begin{array}{l}\text { Only published } \\
\text { RCTs with an } \\
\text { adult } \\
\text { population } \\
\text { aged } 18 \text { and } \\
\text { more were } \\
\text { included }\end{array}$ & $\begin{array}{l}\text { The results } \\
\text { demonstrated a } \\
\text { significant } \\
\text { increase in the } \\
\text { smoking } \\
\text { abstinence rate } \\
\text { during early } \\
\text { measurement in } \\
\text { the combined } \\
\text { wing compared } \\
\text { with varenicline } \\
\text { only treatment } \\
\text { (OR = 1.50, 95\% } \\
\text { CI: } 1.14,1.97 ; 3 \\
\text { trials) and for } \\
\text { late outcome } \\
\text { measure (OR = } \\
1.62,95 \% \\
\text { CI:1.18, } 2.23 ; 2 \\
\text { trials) }\end{array}$ & $\begin{array}{l}\text { Larger RCTs are } \\
\text { needed to make } \\
\text { more robust } \\
\text { conclusions }\end{array}$ \\
\hline $\begin{array}{l}\mathrm{d} \text { et } \\
014\end{array}$ & $\begin{array}{l}8 \text { trials/ 1,213 } \\
\text { participants }\end{array}$ & $\begin{array}{l}\text { To assess the } \\
\text { effectiveness of } \\
\text { opioid } \\
\text { antagonists in } \\
\text { helping long-term } \\
\text { smoking } \\
\text { cessation }\end{array}$ & $\begin{array}{l}\text { smoking abstinence } \\
\text { /comparing opioid } \\
\text { antagonists to } \\
\text { placebo or an } \\
\text { alternative therapy } \\
\text { for smoking cessation }\end{array}$ & $\begin{array}{l}\text { Adult smokers } \\
\text { that reported } \\
\text { data on } \\
\text { abstinence for } \\
\text { a minimum of } \\
6 \text { months }\end{array}$ & $\begin{array}{l}\text { Eight trials gave } \\
\text { no evidence of a } \\
\text { treatment effect } \\
\text { (RR }=0.97 ; 95 \% \\
\text { CI: } 0.76,1.24) \\
\quad \text { For the } 4 \text { studies } \\
\text { that examined } \\
\text { naltrexone versus } \\
\text { placebo as an } \\
\text { adjunct to NRT } \\
\text { (n=768), the } \\
\text { pooled estimate } \\
\text { was RR =0.95; } \\
\text { 95\% CI: } 0.70, \\
1.30 .\end{array}$ & $\begin{array}{l}\text { The findings } \\
\text { indicate no } \\
\text { beneficial effect } \\
\text { of naltrexone } \\
\text { alone or as an } \\
\text { adjunct to NRT } \\
\text { on smoking } \\
\text { abstinence }\end{array}$ \\
\hline $\begin{array}{l}\text { et } \\
306\end{array}$ & $\begin{array}{l}12 / 4,792 \\
\text { participants }(2,408 \\
\text { NRT, } 2,384 \\
\text { control })\end{array}$ & $\begin{array}{l}\text { To evaluate if the } \\
\text { outcome of a } \\
\text { single treatment } \\
\text { episode with NRT } \\
\text { enhances } \\
\text { smoking } \\
\text { cessation over } \\
\text { many years }\end{array}$ & $\begin{array}{l}\text { Smoking cessation at } \\
\text { the time of follow-up } \\
\text { /Nicotine replacement } \\
\text { therapy }\end{array}$ & $\begin{array}{l}\text { Studies with a } \\
\text { final follow-up } \\
\text { of more than } \\
\text { one year after } \\
\text { the start of } \\
\text { treatment and } \\
\text { only study } \\
\text { arms of } \\
\text { standard } \\
\text { recommended }\end{array}$ & $\begin{array}{l}\text { Pooled effect } \\
\text { provided } \\
\text { evidence for the } \\
\text { efficacy of NRT } \\
\text { in sustaining } \\
\text { smoking } \\
\text { cessation beyond } \\
12 \text { months (OR = } \\
1.99,95 \% \text { CI: } \\
1.50,2.64) \text {-fixed }\end{array}$ & $\begin{array}{l}\text { NRT has a } \\
\text { permanent effect } \\
\text { on smoking } \\
\text { cessation }\end{array}$ \\
\hline
\end{tabular}




\begin{tabular}{|c|c|c|c|c|c|c|}
\hline & & & & $\begin{array}{l}\text { doses of NRT } \\
\text { were included }\end{array}$ & $\begin{array}{l}\text { effect gives the } \\
\text { same result }\end{array}$ & \\
\hline aster & $\begin{array}{l}2 \text { trials / } 976 \\
\text { participants }\end{array}$ & $\begin{array}{l}\text { To determine the } \\
\text { efficacy of silver } \\
\text { acetate products } \\
\text { (gum, lozenge, } \\
\text { spray) in helping } \\
\text { smoking } \\
\text { cessation }\end{array}$ & $\begin{array}{l}\text { Sustained abstinence } \\
\text { from smoking at } 6 \text { to } \\
12 \text { months / silver } \\
\text { acetate }\end{array}$ & $\begin{array}{l}\text { RCTs of silver } \\
\text { acetate for } \\
\text { smoking } \\
\text { cessation with } \\
\text { reports of } \\
\text { smoking } \\
\text { status at least } \\
6 \text { months after } \\
\text { the beginning } \\
\text { of treatment }\end{array}$ & $\begin{array}{l}\text { The pooled } \\
\text { estimate for the } \\
\text { risk ratio for } \\
\text { quitting was RR } \\
=1.04,95 \% \mathrm{CI} \text { : } \\
0.69 ; 2 \text { trials }\end{array}$ & $\begin{array}{l}\text { Silver acetate has } \\
\text { no role in } \\
\text { promoting } \\
\text { smoking } \\
\text { cessation }\end{array}$ \\
\hline son & $\begin{array}{l}8 \text { trials / } 2,813 \\
(1,403 \text { intervention } \\
\text { vs. } 1410 \text { control })\end{array}$ & $\begin{array}{l}\text { To update the } \\
\text { nicotine } \\
\text { preloading } \\
\text { efficacy }\end{array}$ & $\begin{array}{l}\text { Short-term abstinence } \\
\text { and long-term } \\
\text { abstinence at least six } \\
\text { months after quit day } \\
\text { / nicotine replacement } \\
\text { therapy (NRT) whilst } \\
\text { smoking, prior to } \\
\text { quitting (preloading) }\end{array}$ & $\begin{array}{l}\text { Only RCTs, } \\
\text { participants } \\
\text { were cigarette } \\
\text { smokers } \\
\text { attempting to } \\
\text { quit, and } \\
\text { if abstinence } \\
\text { was reported } \\
\text { at a 6-month } \\
\text { follow-up or } \\
\text { later. } \\
\text { Mean age of } \\
\text { study } \\
\text { participants } \\
\text { was } 42 \text { years } \\
\end{array}$ & $\begin{array}{l}\text { There was a } \\
\text { very weak } \\
\text { positive effect of } \\
\text { preloading on } \\
\text { short-term } \\
\text { abstinence (RR = } \\
\text { 1.05, 95\% CI: } \\
\text { 0.92, 1.19) } \\
\text { The pooled } \\
\text { effect on long- } \\
\text { term abstinence } \\
\text { was not } \\
\text { significant (RR = } \\
1.16,95 \% \text { CI: } \\
0.97,1.38) \\
\end{array}$ & $\begin{array}{l}\text { The review found } \\
\text { weak non- } \\
\text { significant effect } \\
\text { of nicotine pre- } \\
\text { loading on } \\
\text { smoking } \\
\text { abstinence }\end{array}$ \\
\hline $\begin{array}{l}\text { e et } \\
009\end{array}$ & $\begin{array}{l}7 \text { trials/ } \\
2,767 \text { participants }\end{array}$ & $\begin{array}{l}\text { To identify the } \\
\text { efficacy and } \\
\text { safety of nicotine } \\
\text { replacement } \\
\text { therapy for } \\
\text { smoking } \\
\text { cessation }\end{array}$ & $\begin{array}{l}\text { Six months' sustained } \\
\text { abstinence starting } \\
\text { any time before the } \\
\text { end of treatment/ } \\
\text { Gum or inhaler } \\
\text { nicotine replacement } \\
\text { therapy }\end{array}$ & \begin{tabular}{|l} 
Only RCTs \\
were eligible, \\
The \\
population \\
comprised \\
smokers who \\
were unable \\
or unwilling to \\
stop abruptly
\end{tabular} & $\begin{array}{l}\text { The proportion } \\
\text { of smokers } \\
\text { achieving } \\
\text { sustained } \\
\text { abstinence at six } \\
\text { months with } \\
\text { nicotine } \\
\text { replacement } \\
\text { therapy was } \\
\text { double that of the } \\
\text { placebo group } \\
\text { (RR = 2.06, 95\% } \\
\text { CI: } 1.34,3.15 ; 5 \\
\text { studies) } \\
\text { The proportion } \\
\text { of smokers } \\
\text { achieving } \\
\text { sustained } \\
\text { abstinence at the } \\
\text { end of follow-up } \\
\text { was RR = 1.72, } \\
\text { 95\% CI: } 1.31 \text {, } \\
2.26 ; 7 \text { studies }\end{array}$ & $\begin{array}{l}\text { Nicotine } \\
\text { replacement } \\
\text { therapy is an } \\
\text { effective } \\
\text { intervention in } \\
\text { achieving } \\
\text { sustained } \\
\text { smoking } \\
\text { abstinence }\end{array}$ \\
\hline tt al., & $\begin{array}{l}\text { NRT }=70 \\
\text { trials/28,343 } \\
\text { participants, } \\
\text { Bupropion=12 } \\
\text { trials/ } 5,228 \\
\text { participants, } \\
\text { Varenicline=4 } \\
\text { trials / 2,528 } \\
\text { participants }\end{array}$ & $\begin{array}{l}\text { To evaluate the } \\
\text { effectiveness of } \\
\text { pharmacotherapy } \\
\text { for smoking } \\
\text { cessation }\end{array}$ & $\begin{array}{l}\text { Smoking cessation at } \\
1 \text { year } \\
\text { short-term smoking } \\
\text { cessation ( } 3 \text { months) / } \\
\text { Any RCT of NRT of } \\
\text { any delivery method, } \\
\text { bupropion or } \\
\text { varenicline }\end{array}$ & $\begin{array}{l}\text { Chemical } \\
\text { confirmation } \\
\text { of smoking } \\
\text { cessation } \\
\text { randomised } \\
\text { controlled } \\
\text { trials }\end{array}$ & $\begin{array}{l}\text { Smoking } \\
\text { cessation } \\
\text { favoured NRT } \\
\text { over controls at } \\
\text { one year (OR = } \\
1.71,95 \% \mathrm{CI} \text { : } \\
\text { 1.55, 1.88) } \\
\text { Smoking } \\
\text { cessation } \\
\text { favoured NRT } \\
\text { over controls at } 3 \\
\text { months (59 trials, } \\
\mathrm{n}=25,294 \\
\text { participants, OR } \\
=1.98,95 \% \text { CI: } \\
\text { 1.77-2.21) } \\
\text { Bupropion was } \\
\text { effective for } \\
\text { smoking } \\
\text { cessation } \\
\text { compared to }\end{array}$ & $\begin{array}{l}\text { NRT, bupropion } \\
\text { and varenicline } \\
\text { all provide } \\
\text { therapeutic } \\
\text { effects in } \\
\text { assisting with } \\
\text { smoking } \\
\text { cessation }\end{array}$ \\
\hline
\end{tabular}




\begin{tabular}{|c|c|c|c|c|c|c|}
\hline & & & & & 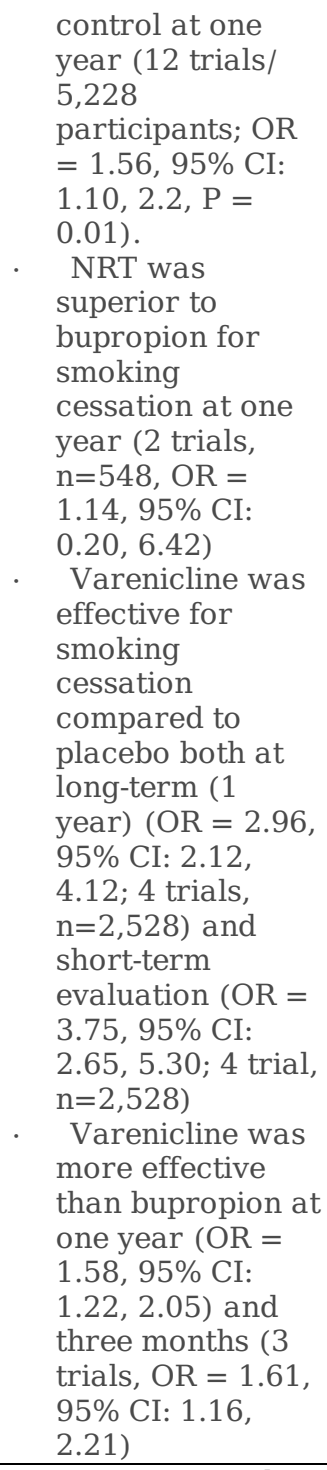 & \\
\hline $\begin{array}{l}. . \text { et } \\
008\end{array}$ & $\begin{array}{l}5 \text { trials } / 2,204 \\
\text { participants }\end{array}$ & $\begin{array}{l}\text { To determine } \\
\text { whether } \\
\text { combination } \\
\text { therapy for } \\
\text { smoking } \\
\text { cessation with } \\
\text { first line agents is } \\
\text { more effective } \\
\text { than } \\
\text { monotherapy }\end{array}$ & $\begin{array}{l}\text { Abstinence at } 3,6 \text { and } \\
12 \text { month of follow } \\
\text { up/ Clinical trials } \\
\text { evaluating } \\
\text { combination therapy } \\
\text { using first line agents } \\
\text { (all trials include } \\
\text { nicotine replacement } \\
\text { patches along with } \\
\text { one other agent) }\end{array}$ & $\begin{array}{l}\text { Double } \\
\text { blind } \\
\text { randomized } \\
\text { placebo } \\
\text { controlled } \\
\text { trial } \\
\text { Study } \\
\text { duration of } \\
\text { one year or } \\
\text { more } \\
\text { Sample } \\
\text { size } \geq 200 \\
\text { Using first } \\
\text { line } \\
\text { smoking } \\
\text { cessation } \\
\text { therapies }\end{array}$ & $\begin{array}{l}\text { Comparing the } \\
\text { combination and } \\
\text { single agent } \\
\text { therapy at } 3 \\
\text { months, the rate } \\
\text { of abstinence was } \\
\text { RR }=1.42,95 \% \\
\text { CI: } 1.21,1.67 \text { ( } 4 \\
\text { trials) } \\
\text { Comparing the } \\
\text { combination and } \\
\text { single agent } \\
\text { therapy at } 6 \\
\text { months, the rate } \\
\text { of abstinence was } \\
\text { RR }=1.54,95 \% \\
\text { CI: } 1.19,2.00 \text { ( } 4 \\
\text { trials) } \\
\text { Comparing the } \\
\text { combination and } \\
\text { single agent } \\
\text { therapy at } 12 \\
\text { months, the rate } \\
\text { of abstinence was } \\
\text { RR }=1.58,95 \% \\
\text { CI } 1.25,1.99 \text { ( } 4 \\
\text { trials) } \\
\end{array}$ & $\begin{array}{l}\text { The author } \\
\text { recommended } \\
\text { future research } \\
\text { to consider } \\
\text { optimal therapy } \\
\text { combination, } \\
\text { duration of } \\
\text { therapy and } \\
\text { preferred agent } \\
\text { for special } \\
\text { population }\end{array}$ \\
\hline $\begin{array}{l}\mathrm{P} \text { et } \\
13\end{array}$ & $\begin{array}{l}7 \text { trials/4020 } \\
\text { participants }(2141\end{array}$ & $\begin{array}{l}\text { To assess the } \\
\text { efficacy of } \\
\text { cytisine in }\end{array}$ & $\begin{array}{l}\text { Smoking quit rate/ } \\
\text { Cytisine therapy }\end{array}$ & $\begin{array}{r}\text { only RCTs } \\
\text { are eligible }\end{array}$ & $\begin{array}{l}\text { Cytisine is an } \\
\text { effective } \\
\text { treatment for }\end{array}$ & $\begin{array}{l}\text { Cytisine is an } \\
\text { effective } \\
\text { treatment for }\end{array}$ \\
\hline
\end{tabular}




\begin{tabular}{|l|l|}
$\begin{array}{l}\text { intervention and } \\
1879 \text { control) }\end{array}$ & $\begin{array}{l}\text { smoking } \\
\text { cessation. }\end{array}$ \\
\\
\\
\end{tabular}

smoking

cessation

compared to

placebo $((\mathrm{RR}=$

1.57, 95\% CI:

1.42 to 1.74 ) at 3

to 2 years follow-

up.

Data from two

high-quality

studies shown

that Cytisine is

effective at 6

months follow-up

$(\mathrm{RR}=3.29 .95 \%$

CI: 1.84 to 5.90$)$.

Table 4: Methods of smoking cessation validation and quality assessment tool used and reported heterogeneity of the reviews

\begin{tabular}{|c|c|c|c|c|c|}
\hline $\begin{array}{l}\text { Authors } \\
\text { and year }\end{array}$ & $\begin{array}{l}\text { Validation of smoking } \\
\text { cessation of included } \\
\text { review }\end{array}$ & $\begin{array}{l}\text { Quality assessment tool and } \\
\text { source }\end{array}$ & $\begin{array}{l}\text { Meta- } \\
\text { analysis } \\
\text { model }\end{array}$ & $\begin{array}{l}\text { Reported } \\
\text { effect } \\
\text { size }\end{array}$ & $\begin{array}{l}\text { Reported heterogeneity of the } \\
\text { reviews }\end{array}$ \\
\hline $\begin{array}{l}\text { Apollonio } \\
\text { et al., } \\
2016\end{array}$ & $\begin{array}{l}\text { Self-reported tobacco } \\
\text { use or biochemical } \\
\text { validation }\end{array}$ & Cochrane risk of assessment tool & $\begin{array}{l}\text { Fixed } \\
\text { effect }\end{array}$ & $\mathrm{RR}$ & $\begin{array}{l}\mathrm{I}^{2}=64 \% \text { for overall } \\
\text { pharmacotherapy }\end{array}$ \\
\hline $\begin{array}{l}\text { Chang et } \\
\text { al., } 2015\end{array}$ & Biochemical verification & Jadad score & $\begin{array}{l}\text { Fixed } \\
\text { effect }\end{array}$ & OR & $\begin{array}{l}\mathrm{I}^{2}=0 \% \text { for early outcome } \\
\text { measure and } 54 \% \text { for late } \\
\text { outcome measures }\end{array}$ \\
\hline $\begin{array}{l}\text { David et } \\
\text { al., } 2014\end{array}$ & $\begin{array}{l}\text { Self-reported or } \\
\text { biochemical verification }\end{array}$ & Cochrane risk of assessment tool & $\begin{array}{l}\text { Fixed } \\
\text { effect }\end{array}$ & $\mathrm{RR}$ & $\mathrm{I}^{2}=0 \%$ \\
\hline $\begin{array}{l}\text { Etter et } \\
\text { al., } 2006\end{array}$ & $\begin{array}{l}\text { Biochemically verified } \\
\text { abstinence }\end{array}$ & Not stated & $\begin{array}{l}\text { Random } \\
\text { effect }\end{array}$ & OR & $\begin{array}{l}\text { Q statistics was } 18.7(\mathrm{p}=0.08)- \\
\text { No evidence of heterogeneity }\end{array}$ \\
\hline $\begin{array}{l}\text { Lancaster } \\
\text { et al., } \\
2012\end{array}$ & $\begin{array}{l}\text { Biochemically verified } \\
\text { abstinence }\end{array}$ & Cochrane risk of assessment tool & $\begin{array}{l}\text { Fixed } \\
\text { effect }\end{array}$ & RR & $\mathrm{I}^{2}=0.0 \%$ \\
\hline $\begin{array}{l}\text { Lindson } \\
\text { et al., } \\
2011\end{array}$ & $\begin{array}{l}\text { Biochemically verified } \\
\text { abstinence and/or self- } \\
\text { report }\end{array}$ & Cochrane risk of assessment tool & $\begin{array}{l}\text { Fixed- } \\
\text { effect }\end{array}$ & RR & $\begin{array}{l}\text { For short-term abstinence } \mathrm{I}^{2} \text { of } \\
69 \% \text { and for } \\
\text { long-term abstinence } \mathrm{I}^{2} \text { of } 39 \%\end{array}$ \\
\hline $\begin{array}{l}\text { Moore } \\
\text { al., } 2009\end{array}$ & $\begin{array}{l}\text { Biochemical (exhaled } \\
\text { carbon monoxide) }\end{array}$ & $\begin{array}{l}\text { Standard guidelines of NHS } \\
\text { Centre for Reviews and } \\
\text { Dissemination }\end{array}$ & $\begin{array}{l}\text { Fixed- } \\
\text { effect }\end{array}$ & $\mathrm{RR}$ & $\mathrm{I}^{2}=52.4 \%$ \\
\hline $\begin{array}{l}\text { Wu. et al., } \\
2006\end{array}$ & Biochemically verified & Cochrane risk of assessment tool & $\begin{array}{l}\text { Random } \\
\text { effect }\end{array}$ & RR & $\mathrm{I}^{2}=20.5$ to $71.5 \%$ \\
\hline $\begin{array}{l}\text { Shah et } \\
\text { al., } 2008\end{array}$ & Biochemically verified & Not stated & \begin{tabular}{|l|}
$\begin{array}{l}\text { Random } \\
\text { effect }\end{array}$ \\
\end{tabular} & OR & $\mathrm{I}^{2}=0 \%$ to $37 \%$ \\
\hline $\begin{array}{l}\text { Hajek P et } \\
\text { al.,2013 }\end{array}$ & $\begin{array}{l}\text { Self-reported or } \\
\text { Biochemically verified }\end{array}$ & $\begin{array}{l}\text { National Institute for Health and } \\
\text { Clinical Excellence (NICE) } \\
\text { Check list }\end{array}$ & $\begin{array}{l}\begin{array}{l}\text { Fixed- } \\
\text { effect }\end{array} \\
\end{array}$ & RR & $\mathrm{I}^{2}=14$ to $76 \%$ \\
\hline
\end{tabular}

Table 5: Systematic review quality $(\mathrm{N}=9)$. 


\begin{tabular}{|c|c|c|c|c|c|c|c|c|c|c|}
\hline $\begin{array}{l}\text { AMSTAR } \\
2 \text { items }^{\text {a }}\end{array}$ & \begin{tabular}{|l|} 
Apollonio \\
et al., 2016
\end{tabular} & $\begin{array}{l}\text { Chang et } \\
\text { al., } 2015\end{array}$ & $\begin{array}{l}\text { David et } \\
\text { al., } 2014\end{array}$ & $\begin{array}{l}\text { Etter. et } \\
\text { al, } 2006\end{array}$ & $\begin{array}{l}\text { Lancaster } \\
\text { et al., } 2012\end{array}$ & \begin{tabular}{|l|} 
Lindson et \\
al., 2011
\end{tabular} & $\begin{array}{l}\text { Moore et } \\
\text { al., } 2009\end{array}$ & $\begin{array}{l}\text { Wu et } \\
\text { al., } 2006\end{array}$ & $\begin{array}{l}\text { Shah et } \\
\text { al., } 2008\end{array}$ & $\begin{array}{l}\text { Hajek P } \\
\text { et } \\
\text { al.,2013 }\end{array}$ \\
\hline Q1 & $\mathrm{Y}$ & $\mathrm{Y}$ & $\mathrm{Y}$ & $\mathrm{Y}$ & $\mathrm{Y}$ & $\mathrm{Y}$ & $\mathrm{Y}$ & $\mathrm{N}$ & $\mathrm{Y}$ & Y \\
\hline Q2* & PY & $\mathrm{N}$ & $\mathrm{N}$ & $\mathrm{N}$ & PY & $\mathrm{N}$ & $\mathrm{N}$ & $\mathrm{N}$ & $\mathrm{N}$ & $\mathrm{N}$ \\
\hline Q3 & $\mathrm{Y}$ & $\mathrm{Y}$ & $\mathrm{Y}$ & $\mathrm{Y}$ & $\mathrm{Y}$ & $\mathrm{Y}$ & $\mathrm{Y}$ & $\mathrm{Y}$ & $\mathrm{Y}$ & $\mathrm{Y}$ \\
\hline Q4* & $\mathrm{Y}$ & $\mathrm{Y}$ & $\mathrm{N}$ & $\mathrm{N}$ & $\mathrm{Y}$ & $\mathrm{N}$ & PY & $\mathrm{N}$ & $\mathrm{N}$ & PY \\
\hline Q5 & $\mathrm{Y}$ & Y & $\mathrm{Y}$ & $\mathrm{N}$ & $\mathrm{Y}$ & $\mathrm{N}$ & $\mathrm{Y}$ & $\mathrm{Y}$ & $\mathrm{N}$ & $\mathrm{Y}$ \\
\hline Q6 & $\mathrm{Y}$ & $\mathrm{Y}$ & $\mathrm{Y}$ & $\mathrm{Y}$ & $\mathrm{Y}$ & $\mathrm{N}$ & $\mathrm{Y}$ & $\mathrm{Y}$ & $\mathrm{N}$ & $\mathrm{Y}$ \\
\hline Q7* & $\mathrm{Y}$ & $\mathrm{N}$ & $\mathrm{Y}$ & $\mathrm{Y}$ & $\mathrm{Y}$ & \begin{tabular}{|l|}
$\mathrm{N}$ \\
\end{tabular} & $\mathrm{Y}$ & $\mathrm{N}$ & Y & $\mathrm{N}$ \\
\hline Q8 & $\mathrm{Y}$ & $\mathrm{Y}$ & PY & PY & PY & PY & PY & $\mathrm{N}$ & $\mathrm{N}$ & PY \\
\hline Q9* & $\mathrm{Y}$ & $\mathrm{Y}$ & PY & $\mathrm{N}$ & PY & PY & $\mathrm{Y}$ & PY & $\mathrm{N}$ & PY \\
\hline Q10 & Y & $\mathrm{N}$ & $\mathrm{N}$ & $\mathrm{N}$ & $\mathrm{N}$ & $\mathrm{N}$ & $\mathrm{N}$ & $\mathrm{N}$ & $\mathrm{N}$ & $\mathrm{N}$ \\
\hline Q11* & $\mathrm{Y}$ & $\mathrm{Y}$ & $\mathrm{Y}$ & $\mathrm{Y}$ & $\mathrm{Y}$ & $\mathrm{N}$ & $\mathrm{Y}$ & $\mathrm{Y}$ & $\mathrm{Y}$ & $\mathrm{Y}$ \\
\hline Q12 & Y & $\mathrm{Y}$ & $\mathrm{N}$ & $\mathrm{N}$ & $\mathrm{N}$ & $\mathrm{N}$ & $\mathrm{Y}$ & $\mathrm{Y}$ & $\mathrm{N}$ & $\mathrm{Y}$ \\
\hline Q13* & $\mathrm{Y}$ & $\mathrm{N}$ & $\mathrm{Y}$ & $\mathrm{N}$ & $\mathrm{N}$ & Y & $\mathrm{Y}$ & $\mathrm{N}$ & $\mathrm{N}$ & $\mathrm{Y}$ \\
\hline Q14 & $\mathrm{Y}$ & $\mathrm{Y}$ & $\mathrm{Y}$ & $\mathrm{Y}$ & $\mathrm{Y}$ & $\mathrm{Y}$ & $\mathrm{Y}$ & $\mathrm{Y}$ & $\mathrm{N}$ & $\mathrm{N}$ \\
\hline Q15* & $\mathrm{Y}$ & $\mathrm{Y}$ & $\mathrm{N}$ & $\mathrm{Y}$ & $\mathrm{N}$ & $\mathrm{Y}$ & $\mathrm{Y}$ & $\mathrm{Y}$ & $\mathrm{N}$ & $\mathrm{N}$ \\
\hline Q16 & $\mathrm{Y}$ & $\mathrm{Y}$ & $\mathrm{Y}$ & $\mathrm{Y}$ & $\mathrm{Y}$ & $\mathrm{Y}$ & $\mathrm{Y}$ & $\mathrm{Y}$ & $\mathrm{Y}$ & $\mathrm{Y}$ \\
\hline $\begin{array}{l}\text { Quality of } \\
\text { review }\end{array}$ & High & Low & Low & Low & Low & $\begin{array}{l}\text { Critically } \\
\text { Low }\end{array}$ & Moderate & $\begin{array}{l}\text { Critically } \\
\text { Low }\end{array}$ & $\begin{array}{l}\text { Critically } \\
\text { Low }\end{array}$ & Moderate \\
\hline
\end{tabular}

Items: Q1) Did the research questions and inclusion criteria for the review include the components of PICO? Q2) Did the report of the review contain an explicit statement that the review methods were established prior to the conduct of the review and did the report justify any significant deviations from the protocol? Q3) Did the review authors explain their selection of the study designs for inclusion in the review? Q4) did the review authors use a comprehensive literature search strategy? Q5) Did the review authors perform study selection in duplicate? Q6) Did the review authors perform data extraction in duplicate? Q7) Did the review authors provide a list of excluded studies and justify the exclusions? Q8) did the review authors describe the included studies in adequate detail? Q9) Did the review authors use a satisfactory technique for assessing the risk of bias (RoB) in individual studies? Q10) Did the review authors report on the sources of funding for the studies included in the review? Q11) If meta-analysis was performed did the review authors use appropriate methods for statistical combination of results? Q12) If meta-analysis was performed, did the review authors assess the potential impact of RoB in individual studies on the results of the meta-analysis or other evidence synthesis? Q13) Did the review authors account for RoB in individual studies when interpreting/ discussing the results of the review? Q14) Did the review authors provide a satisfactory explanation for, and discussion of, any heterogeneity observed in the results of the review? Q15) If they performed quantitative synthesis did the review authors carry out an adequate investigation of publication bias (small study bias) and discuss its likely impact on the results of the review? Q16) Did the review authors report any potential sources of conflict of interest, including any funding they received for conducting the review?

* Critical domains.

AMSTAR= Assessing the Methodological Quality of Systematic Reviews; Y=Yes; N=No; PY=partial yes;

\section{Figures}

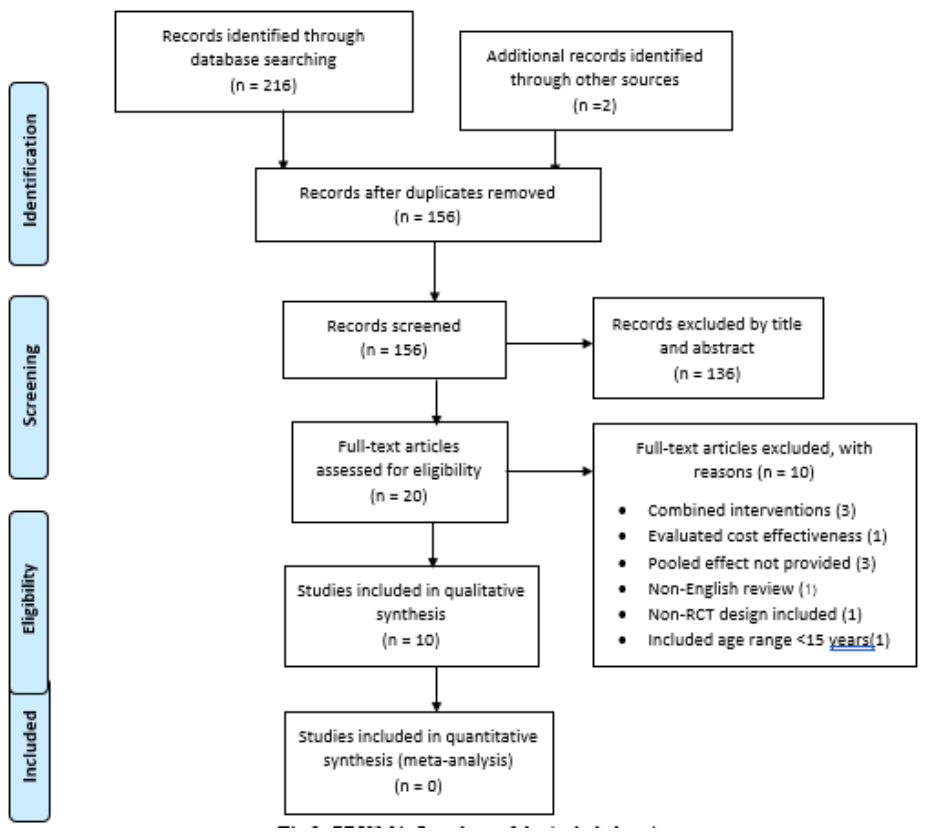

Figure 1

PRISMA flowchart of the included reviews 


\section{Supplementary Files}

This is a list of supplementary files associated with this preprint. Click to download.

- Additionalfile2SearchstrategyinMedline.docx

- Additionalfile3Dataabstractionform.docx

- Additionalfile1PRISMAchecklist.doc

- AdditionalFile4RAMSTARChecklist.pdf

- Additionalfile4AMSTAR2checklist.pdf 